\title{
CHARACTERIZATION AND GENETIC RELATIONSHIPS ANALYSIS OF BUFFALO POPULATION IN MOA ISLAND OF SOUTH-EAST WEST MALUKU REGENCY OF MALUKU PROVINCE
}

\author{
J. F. Salamena and B. J. Papilaja \\ Department of Animal Husbandry, Faculty of Agriculture, Pattimura University \\ Jl. Ir. M. Putuhena Kampus Poka , Ambon 97233 - Indonesia \\ Corresponding E-mail: jerrysalamena@yahoo.com \\ Received January 17, 2009; Accepted March 18, 2010
}

\begin{abstract}
The research aim was to study the variance of some morphometric characteristics and morphology of Moa buffalo, and the genetic relationships analysis between buffalo subpopulations in Moa Island. Characterization was by using 174 buffalos from any group of ages and sex that were collected from West area (Werwaru, Patti), Central area (Syota, Klis) and East area (Tounwawan, Poliwu). The variables observed were morphometric characters (body weight, shoulder height, body length, chest width, chest depth, chest girth, skull length, skull width, skull height, ear width, ear length, cannon girth, horn length, horn girth and distance between horns), body morphology characters (horn position, head color, body color and scheme of body color), and genetic distance between buffalo subpopulations. Body morphometric data were analyzed using mean, standard deviation and variance coefficient. Body morphology data were analyzed using relative frequencies. The genetic distance was analyzed using canonical discriminant function through Mahalanobis distance approach and by making phylogeny using UPGMA method. The result indicated that variation of body morphometric was related to production performance, variation of color and color scheme of body. Based on genetic distance, central and west subpopulations were the nearest where West subpopulation was isolated from Central and East subpopulation.
\end{abstract}

Keywords: characterization, genetic distance, Moa buffalo

\section{INTRODUCTION}

The national food demand can be fulfilled by chicken and cattle products such as meat, milk and egg. Meat is the most consumed product. The high demand and consumption caused the government has to determine towards the meat sufficiency in 2010. One of the important things to support that program is through the population improvement and its productivity. With this program, the attention of the government is directed for the production development, the increase in population and genetic will improve the quality of local cattle (Puslitnak, 2006)

Study by FAO (2002) showed that local cattles have specific superiority, i.e they can live longer with low quality of feed, can live under extreme local climate, are highly resistance against disease and local parasite, are specific gene sources for the improvement of cattle races through crossing, are more productive with low cost and are available for the long term, support food, agriculture, and cultural diversity, also are more effective to fulfill the local food security.

Local buffalo has been chosen by the government as a complement and substitute for cow to fulfill the national need of meat. Buffalo (Bubalus bubalis) has very strategic role and functions in the lives of Indonesian community, i.e. as meat product substituting cow, as commercial commodity in weight increase, as integral farming activity in using the agricultural waste, as important component in the community socio-culture and can be used for hobby, agrotourism, and sport (Pustlitnak, 2006).

Cow and buffalo meat production in 2012 for Maluku Province is predicted to be 4,510,845 $\mathrm{kg} /$ year, meanwhile in 2008 the production was only $1,938,374 \mathrm{~kg} /$ year, therefore the deficit of meat production was about $2,572,471 \mathrm{~kg} /$ year or equals to 17,149 cows or cattle (Departemen Pertanian Provinsi Maluku, 2008). Buffalo plays an important role in the farmer's socio-economy, as a live savings, the farmers' social status, as source of workers, and to produce meat, milk and biofertilizer (Diwiyanto and Subandriyo, 1995). 
According to Yusdja et al. (2003), as a meat product, the development of buffalo population is relatively slowly, therefore the productivity is low. The productivity improvement can be done through the improvement of genetic quality of buffalo. The buffalo genetic improvement can be done by cattle breeding, either through selection or crossing.

Towards the activity of cattle breeding, data base (recording) about the important characteristics (especially production characteristics) is needed as a model for running the cattle breeding program. The specific information about the Moa buffalo is not much known. Therefore, this research was conducted to study the variability of several morphometric characters and morphology of Moa buffalo, and the genetic relationships analysis between buffalo subpopulation in Moa island.

\section{MATERIALS AND METHOD}

The buffalo characterization research was conducted in Moa island of South-East West Maluku Regency, Maluku Province. Materials used were 174 buffaloes ( 83 male, 91 female), classified according to their age and sex. Age groupings were below 1 year old (y.o), between 12 y.o, between 2-3 y.o, between 3-4 y.o, between 4-5 y.o, and above 5 y.o. The age determination was based on the information of farmers or the development of teeth acoording to Djanah (1984).

The method used was survey method by measurement and direct observation in the field. The region of Moa island was divided into 3 regions (subpopulations): West area of Moa (Werwaru dan Patti villages), central area (Syota neighbourhood and Klis village) and Eastern Moa (Tounwawan village and Poliwu neighbourhood) based on the representative distribution of buffalo population in Moa island. From three subpopulation, 174 buffalos were collected for characterization.

Morphometric variables observed were body weight (BW) predicted by regression equation Weight $=383.59+3.581$ Chest girth, shoulder height $(\mathrm{SH})$, body length (BL), chest depth (CD), chest girth (CG), skull length (SL), skull width (SW), skull height (SH), ear length (EL), ear width (EW), cannon girth (CG), horn length (HL), and distance between horns (DBH). Body morphology characteristics observed were horn position, head colour, body color and scheme. The genetic distance was observed to see the genetic relationships between buffallo subpopulations in Moa island.

Data analysis of morphometic measurement used mean values, standard deviation and coefficient variation according to Walpole (1995). Meanwhile, the determination of genetic distance between subpopulation used discriminant function. Discriminant function using Mahalanobis distance approach is a measure of minimum genetic quadratic distance (Manly, 1989 and Herera et al., 1996), written as:

$$
D_{i, j}^{2}=\left(\bar{X}_{i}-\bar{X}_{j}\right) C^{-1}\left(X_{i}-X_{j}\right)
$$

Where:

$$
\begin{aligned}
D_{i, j}^{2}= & \text { Mahalanobis statistical value as a } \\
& \text { measure of quadratic distance between } \\
& \text { buffalo subpopulation to-I and } \\
& \text { subpopulation to-j. } \\
C^{-1}= & \text { Inverse matrix of all covariance between } \\
\text { variable. } & \\
\mathrm{X}_{\mathrm{i}}= & \text { Mean vector value of observation from } \\
& \text { buffalo subpopulation to-i at each body } \\
& \text { morphometric variable. } \\
\mathrm{X}_{\mathrm{j}}= & \text { Mean vector value of observation from } \\
& \text { buffalo subpopulation to-j at each body } \\
& \text { morphometric variable. }
\end{aligned}
$$

Phylogeny analysis used UPGMA (Unweighted Pair Group with Arithmatic) method assuming the same rate of evolution between subpopulation (Kumar et al., 1993). Data analysis used statistical package program SAS version 9.00 and genetic package program Mega version 2.0.

\section{RESULTS AND DISCUSSION}

\section{Morphometric Characteristic}

The results of body morphometric characteristic related to the production of male and female buffalo at all ages are shown in Table 1.

Table 1 showed that, there was high variation of body weight reflected from the coefficient value. In general, body weight varies at all ages, both in male and female buffalos. Age group of 1-2 years has highest coefficient of variation value (103.61 at male and 57.13 at female), followed by other age groups. Body weight is a character which depend much more on the feed supply/availability causing the high variation between individual buffalo.

For character shoulder height, high variation 
Tabel 1. Body Morphometric Characteristic Related to the Production of Moa Buffalo

\begin{tabular}{|c|c|c|c|c|c|c|c|}
\hline \multirow{3}{*}{ Body size } & \multirow{3}{*}{$\begin{array}{l}\text { Age of Buffalo } \\
\text { (Year) }\end{array}$} & \multicolumn{6}{|c|}{ Sex } \\
\hline & & \multicolumn{3}{|c|}{ Male } & \multicolumn{3}{|c|}{ Female } \\
\hline & & Mean \pm SD & $\mathrm{CV}$ & $\mathrm{n}$ & Mean \pm SD & $\mathrm{CV}$ & $\mathrm{n}$ \\
\hline \multirow{5}{*}{ Body weight (kg) } & $1-2$ & $79.80 \pm 82.70$ & 103.61 & 11 & $119.50 \pm 68.30$ & 57.13 & 11 \\
\hline & $2-3$ & $186.10 \pm 34.16$ & 18.35 & 24 & $171.20 \pm 67.20$ & 39.27 & 11 \\
\hline & $3-4$ & $228.40 \pm 51.30$ & 22.47 & 17 & $215.68 \pm 30.89$ & 14.32 & 15 \\
\hline & $4-5$ & $288.20 \pm 49.10$ & 17.02 & 5 & $279.70 \pm 45.20$ & 16.15 & 13 \\
\hline & $>5$ & $310.60 \pm 58.00$ & 18.67 & 11 & $304.36 \pm 46.54$ & 15.29 & 24 \\
\hline \multirow{6}{*}{$\begin{array}{l}\text { Should er height } \\
(\mathrm{cm})\end{array}$} & $<1$ & $82.17 \pm 10.22$ & 12.44 & 15 & $84.44 \pm 9.18$ & 10.87 & 17 \\
\hline & $1-2$ & $94.48 \pm 15.71$ & 16.63 & 11 & $101.05 \pm 11.27$ & 11.15 & 11 \\
\hline & $2-3$ & $107.61 \pm 7.33$ & 6.81 & 24 & $105.89 \pm 8.77$ & 8.28 & 11 \\
\hline & $3-4$ & $114.36 \pm 6.23$ & 5.45 & 17 & $111.21 \pm 7.69$ & 6.92 & 15 \\
\hline & $4-5$ & $117.92 \pm 6.22$ & 5.28 & 5 & $117.12 \pm 5.55$ & 4.74 & 13 \\
\hline & $>5$ & $120.77 \pm 8.60$ & 7.12 & 11 & $118.88 \pm 6.80$ & 5.72 & 24 \\
\hline \multirow{6}{*}{ Body length $(\mathrm{cm})$} & $<1$ & $70.43 \pm 14.78$ & 20.98 & 15 & $69.34 \pm 13.48$ & 19.44 & 17 \\
\hline & $1-2$ & $80.26 \pm 14.97$ & 18.66 & 11 & $84.16 \pm 9.21$ & 10.95 & 11 \\
\hline & $2-3$ & $97.01 \pm 9.23$ & 9.52 & 24 & $94.64 \pm 12.51$ & 13.22 & 11 \\
\hline & $3-4$ & $105.03 \pm 9.07$ & 8.64 & 17 & $104.20 \pm 5.33$ & 5.12 & 15 \\
\hline & $4-5$ & $116.18 \pm 10.52$ & 9.06 & 5 & $105.51 \pm 4.64$ & 4.4 & 13 \\
\hline & $>5$ & $114.01 \pm 12.99$ & 11.39 & 11 & $117.03 \pm 7.83$ & 6.69 & 24 \\
\hline \multirow{6}{*}{ Chest width $(\mathrm{cm})$} & $<1$ & $26.01 \pm 5.30$ & 20.36 & 15 & $27.48 \pm 5.31$ & 19.34 & 17 \\
\hline & $1-2$ & $30.77 \pm 5.89$ & 19.16 & 11 & $34.26 \pm 5.64$ & 16.47 & 11 \\
\hline & $2-3$ & $38.34 \pm 8.77$ & 22.89 & 24 & $39.76 \pm 7.01$ & 17.63 & 11 \\
\hline & $3-4$ & $42.40 \pm 4.36$ & 10.28 & 17 & $41.84 \pm 4.54$ & 10.84 & 15 \\
\hline & $4-5$ & $46.96 \pm 3.96$ & 8.42 & 5 & $44.62 \pm 2.34$ & 5.25 & 13 \\
\hline & $>5$ & $45.89 \pm 10.22$ & 22.27 & 11 & $45.50 \pm 8.08$ & 17.77 & 24 \\
\hline \multirow{6}{*}{ Chest depth $(\mathrm{cm})$} & $<1$ & $40.83 \pm 40.83$ & 15.69 & 15 & $41.96 \pm 8.29$ & 19.75 & 17 \\
\hline & $1-2$ & $51.42 \pm 51.42$ & 18.3 & 11 & $52.71 \pm 6.08$ & 11.53 & 11 \\
\hline & $2-3$ & $58.72 \pm 58.72$ & 15.26 & 24 & $59.88 \pm 8.10$ & 13.53 & 11 \\
\hline & $3-4$ & $66.12 \pm 66.12$ & 6.7 & 17 & $63.55 \pm 5.36$ & 8.43 & 15 \\
\hline & $4-5$ & $70.22 \pm 70.22$ & 5.92 & 5 & $71.85 \pm 5.28$ & 7.34 & 13 \\
\hline & $>5$ & $72.85 \pm 72.85$ & 10.51 & 11 & $71.83 \pm 6.81$ & 9.49 & 24 \\
\hline \multirow{6}{*}{ Chest girth (cm) } & $<1$ & $103.14 \pm 18.26$ & 17.7 & 15 & $101.48 \pm 18.87$ & 18.6 & 17 \\
\hline & $1-2$ & $129.40 \pm 23.09$ & 17.84 & 11 & $140.50 \pm 19.07$ & 13.57 & 11 \\
\hline & $2-3$ & $159.09 \pm 9.54$ & 6 & 24 & $154.92 \pm 18.77$ & 12.12 & 11 \\
\hline & $3-4$ & $170.91 \pm 14.33$ & 8.39 & 17 & $167.35 \pm 8.62$ & 5.15 & 15 \\
\hline & $4-5$ & $187.60 \pm 13.70$ & 7.3 & 5 & $185.23 \pm 12.61$ & 6.81 & 13 \\
\hline & $>5$ & $193.85 \pm 16.19$ & 8.35 & 11 & $192.11 \pm 13.00$ & 6.77 & 24 \\
\hline
\end{tabular}

Note: SD is standard deviation, $\mathrm{CV}$ is coefficient of variation and $\mathrm{n}$ is the number of buffalo samples.

(above 15\%) occurred at age group 1-2 years for male, and tend to be homogen for female (below $15 \%)$. For character body length, high variation occurred at age group 1-2 year, meanwhile for female happened at age below 1 year. For character chest width, high variation was found at age group below 1-3 years, both for male and female. For character chest depth, high variation is at age below 1-3 years, meanwhile for female is only at age below 1 year. For character chest girth, variation occurred at age below 1-2 years for male, and below 1-3 years for female. The variation of the above morphometric characters can be taken as selection character for the improvement of Moa buffalo genetic quality.

Low variation (below 15\%) of morphometric characters is related to production performance of buffalo at age above 3 years, because generally the growth phase is slower and tend to be similar. Other factor, possibly the buffalo were sold or slaughtered (especially the ones with high quality in weight and size), because of easily sold with 
Table 2. Other Diagnostic Morphometric Characters of Moa Buffalo

\begin{tabular}{|c|c|c|c|c|c|c|c|}
\hline \multirow{3}{*}{ Body size } & \multirow{3}{*}{$\begin{array}{c}\text { Age of Buffalo } \\
\text { (Year) }\end{array}$} & \multicolumn{6}{|c|}{ Sex } \\
\hline & & \multicolumn{3}{|c|}{ Male } & \multicolumn{3}{|c|}{ Female } \\
\hline & & Mean \pm SD & $\mathrm{CV}$ & $\mathbf{n}$ & Mean \pm SD & $\mathrm{CV}$ & $\mathbf{n}$ \\
\hline \multirow{6}{*}{ Cannon girth (cm) } & $<1$ & $15.69 \pm 1.89$ & 12.02 & 15 & $14.19 \pm 2.10$ & 14.77 & 17 \\
\hline & $1-2$ & $17.61 \pm 2.62$ & 14.89 & 11 & $2.57 \pm 15.07$ & 15.07 & 11 \\
\hline & $2-3$ & $19.39 \pm 1.64$ & 8.44 & 24 & $2.08 \pm 10.62$ & 10.62 & 11 \\
\hline & $3-4$ & $21.16 \pm 2.19$ & 10.37 & 17 & $2.74 \pm 14.27$ & 14.27 & 15 \\
\hline & $4-5$ & $22.82 \pm 1.02$ & 4.45 & 5 & $1.26 \pm 6.10$ & 6.1 & 13 \\
\hline & $>5$ & $22.55 \pm 1.82$ & 7.82 & 11 & $1.12 \pm 5.38$ & 5.38 & 24 \\
\hline \multirow{6}{*}{ Skull length $(\mathrm{cm})$} & $<1$ & $24.08 \pm 5.68$ & 23.59 & 15 & $24.53 \pm 4.96$ & 20.22 & 17 \\
\hline & $1-2$ & $32.76 \pm 3.85$ & 11.74 & 11 & $31.85 \pm 5.13$ & 16.1 & 11 \\
\hline & $2-3$ & $38.78 \pm 2.98$ & 7.68 & 24 & $36.76 \pm 3.23$ & 8.79 & 11 \\
\hline & $3-4$ & $41.82 \pm 1.95$ & 4.67 & 17 & $40.18 \pm 1.95$ & 4.85 & 15 \\
\hline & $4-5$ & $38.70 \pm 9.18$ & 23.72 & 5 & $40.94 \pm 2.07$ & 5.05 & 13 \\
\hline & $>5$ & $46.17 \pm 2.55$ & 5.53 & 11 & $44.29 \pm 2.44$ & 5.51 & 24 \\
\hline \multirow{6}{*}{ Skull width (cm) } & $<1$ & $10.34 \pm 5.30$ & 2.05 & 15 & $10.42 \pm 2.19$ & 21.04 & 17 \\
\hline & $1-2$ & $12.04 \pm 5.89$ & 1.97 & 11 & $1.70 \pm 1.70$ & 13.66 & 11 \\
\hline & $2-3$ & $15.08 \pm 8.77$ & 3.2 & 24 & $1.47 \pm 1.47$ & 10.26 & 11 \\
\hline & $3-4$ & $17.61 \pm 4.36$ & 2.82 & 17 & $15.21 \pm 2.15$ & 14.12 & 15 \\
\hline & $4-5$ & $16.44 \pm 3.96$ & 3.32 & 5 & $15.94 \pm 3.14$ & 19.73 & 13 \\
\hline & $>5$ & $22.28 \pm 10.22$ & 2.62 & 11 & $19.95 \pm 3.19$ & 16.01 & 24 \\
\hline \multirow{6}{*}{ Skull height $(\mathrm{cm})$} & $<1$ & $17.87 \pm 2.40$ & 13.45 & 15 & $17.78 \pm 3.52$ & 19.77 & 17 \\
\hline & $1-2$ & $23.51 \pm 3.76$ & 15.97 & 11 & $23.17 \pm 3.02$ & 13.02 & 11 \\
\hline & $2-3$ & $27.87 \pm 3.78$ & 13.57 & 24 & $25.24 \pm 2.20$ & 8.71 & 11 \\
\hline & $3-4$ & $29.52 \pm 3.21$ & 10.87 & 17 & $26.57 \pm 2.05$ & 7.73 & 15 \\
\hline & $4-5$ & $33.26 \pm 6.59$ & 19.81 & 5 & $27.26 \pm 3.18$ & 11.66 & 13 \\
\hline & $>5$ & $32.90 \pm 2.54$ & 7.73 & 11 & $29.57 \pm 2.38$ & 8.04 & 24 \\
\hline \multirow{6}{*}{ Horn length (cm) } & $<1$ & $8.64 \pm 9.33$ & 107.94 & 15 & $5.21 \pm 4.66$ & 89.49 & 17 \\
\hline & $1-2$ & $15.83 \pm 6.32$ & 39.92 & 11 & $16.81 \pm 5.56$ & 33.08 & 11 \\
\hline & $2-3$ & $28.41 \pm 5.23$ & 18.42 & 24 & $24.02 \pm 6.88$ & 28.66 & 11 \\
\hline & $3-4$ & $34.38 \pm 3.65$ & 10.63 & 17 & $32.04 \pm 5.15$ & 16.09 & 15 \\
\hline & $4-5$ & $39.14 \pm 8.43$ & 21.53 & 5 & $49.08 \pm 5.81$ & 11.84 & 13 \\
\hline & $>5$ & $49.55 \pm 16.66$ & 33.63 & 11 & $57.30 \pm 12.46$ & 21.74 & 24 \\
\hline \multirow{6}{*}{ Horn girth (cm) } & $<1$ & $12.32 \pm 4.36$ & 35.41 & 15 & $10.64 \pm 3.52$ & 33.11 & 17 \\
\hline & $1-2$ & $17.28 \pm 6.49$ & 37.53 & 11 & $17.36 \pm 2.99$ & 17.25 & 11 \\
\hline & $2-3$ & $26.71 \pm 3.52$ & 13.18 & 24 & $21.98 \pm 3.99$ & 18.14 & 11 \\
\hline & $3-4$ & $31.28 \pm 2.46$ & 7.85 & 17 & $24.55 \pm 2.44$ & 9.93 & 15 \\
\hline & $4-5$ & $35.94 \pm 2.17$ & 6.05 & 5 & $25.48 \pm 2.24$ & 8.78 & 13 \\
\hline & $>5$ & $36.00 \pm 3.52$ & 9.78 & 11 & $26.95 \pm 2.58$ & 9.56 & 24 \\
\hline \multirow{6}{*}{$\begin{array}{l}\text { Distance between } \\
\text { horn }(\mathrm{cm})\end{array}$} & $<1$ & $11.90 \pm 18.26$ & 17.06 & 15 & $11.82 \pm 1.50$ & 12.61 & 17 \\
\hline & $1-2$ & $14.32 \pm 23.09$ & 18.34 & 11 & $14.29 \pm 1.66$ & 11.64 & 11 \\
\hline & $2-3$ & $15.26 \pm 9.54$ & 13.02 & 24 & $15.04 \pm 2.33$ & 15.5 & 11 \\
\hline & $3-4$ & $16.06 \pm 14.33$ & 14.91 & 17 & $16.69 \pm 1.85$ & 11.11 & 15 \\
\hline & $4-5$ & $16.76 \pm 13.70$ & 21.17 & 5 & $17.68 \pm 1.79$ & 10.11 & 13 \\
\hline & $>5$ & $16.11 \pm 16.19$ & 22.13 & 11 & $18.08 \pm 3.10$ & 17.16 & 24 \\
\hline \multirow{6}{*}{ Ear width $(\mathrm{cm})$} & $<1$ & $12.55 \pm 2.09$ & 16.65 & 15 & $11.62 \pm 1.41$ & 12.1 & 17 \\
\hline & $1-2$ & $13.42 \pm 1.16$ & 8.68 & 11 & $13.17 \pm 1.61$ & 12.25 & 11 \\
\hline & $2-3$ & $14.42 \pm 1.51$ & 10.44 & 24 & $14.29 \pm 1.36$ & 9.55 & 11 \\
\hline & $3-4$ & $15.58 \pm 1.68$ & 10.79 & 17 & $14.71 \pm 1.24$ & 8.44 & 15 \\
\hline & $4-5$ & $15.22 \pm 1.56$ & 10.25 & 5 & $15.19 \pm 1.03$ & 6.78 & 13 \\
\hline & $>5$ & $16.13 \pm 2.01$ & 12.48 & 11 & $15.79 \pm 1.57$ & 9.93 & 24 \\
\hline \multirow{6}{*}{ Ear length $(\mathrm{cm})$} & $<1$ & $16.29 \pm 2.36$ & 14.46 & 15 & $15.45 \pm 1.93$ & 12.47 & 17 \\
\hline & $1-2$ & $17.57 \pm 2.06$ & 11.71 & 11 & $17.61 \pm 1.79$ & 10.19 & 11 \\
\hline & $2-3$ & $19.15 \pm 1.50$ & 7.81 & 24 & $19.21 \pm 2.59$ & 13.5 & 11 \\
\hline & $3-4$ & $21.01 \pm 3.46$ & 16.49 & 17 & $18.98 \pm 1.55$ & 8.15 & 15 \\
\hline & $4-5$ & $19.56 \pm 1.32$ & 6.75 & 5 & $20.03 \pm 2.02$ & 10.09 & 13 \\
\hline & $>5$ & $20.51 \pm 2.50$ & 12.2 & 11 & $19.52 \pm 2.03$ & 10.41 & 24 \\
\hline
\end{tabular}

Note: SD is standard deviation, $\mathrm{CV}$ is coefficient of variation and $\mathbf{n}$ is the number of buffalo samples. 
better price. Furthermore, other diagnostic morphometric characters of Moa buffalo can be seen in Table 2.

\section{Body Morphology Characteristic of Moa Buffalo}

Morphology characteristic of Moa buffalo is given in Table 3. Both male and female buffalo have horn. The form of adult buffalo horn generally curve from its side to the back.

Body color is one specific diagnostic of a cattle race. In Table 3, it can be seen that the color of Moa buffalo body varied highly, with black $(43.67 \%)$ followed by grey $(28.74 \%)$, white
Timor (Noovy-Palm and Hetty, 1979). The color variation of Moa buffalo is different from the buffalo reported by Lendhanie (2005), where the swamp buffalo in Kalimantan is brown grey.

Genetic Relationships and Classification of Buffalo in Moa

The result of plotting the first and second main components is given in Figure 1, which shows that the group distribution in three subpopulation/regions morphometrically is overlapping, however there was a class in certain region. Buffalos in West area tend to make their own group, meanwhile the buffalo in central and East area tend to be in the same group.

Table 3. Morphology Characteristic of Moa Buffalo

\begin{tabular}{ll}
\hline \multicolumn{1}{c}{ Morphology characteristic } & \multicolumn{1}{c}{ Form } \\
\hline Horn position & Curve from its side to the back \\
Head color & Grey $(40.80 \%)$, Black $(44.25 \%)$, and white $(14.94 \%)$. \\
& Grey $(28.74)$, Grey dominant with white $(2.30 \%)$, Black \\
Body color & $(43.67 \%)$, Black dominant with white $(6.32 \%)$, White \\
& $(15.52 \%)$, White dominant with grey $(1.15 \%)$, and white \\
& dominant with black $(2.30)$. \\
Scheme of body color & Big stripe $(9.20 \%)$, small stripe $(0.57)$, dotted (4.02\%), and \\
& solid color $(86.21 \%)$. \\
\hline
\end{tabular}

$(15.52 \%)$ and mixture of three colors (black, white, and grey) is $12.07 \%$. The combination of black and white of Moa buffalo is similar to Bonga buffalo in Toraja. Bonga, buffalo with black and white combination is the most beautiful, and its price reaches ten to hundred millions. Bonga buffalo can be found in the community of Toraja, Central Sulawesi, Sumba, Flores, Roti,
Discriminant analysis on the body morphometric character between Moa buffalo subpopulation resulted the grouping based on the percentage of similarity value and mixture value, in and between subpopulation as given in Table 4. This result showed that the similar value of body morphometric character for each subpopulation is relatively high. West subpopulation $(67.4 \%)$ is

Table 4. Persentage of Similarity and Mixture Values in and between Buffalo Subpopulation in Moa Island

\begin{tabular}{lccccc}
\hline & & \multicolumn{3}{c}{ Subpopulation } & \multirow{2}{*}{ Total } \\
\cline { 3 - 5 } \multicolumn{2}{c}{ Subpopulation } & West & Central & East & \\
\hline \multirow{2}{*}{ West } & $\mathrm{n}$ & 31 & 9 & 6 & 46 \\
& $\%$ & 67.4 & 19.6 & 13 & 100 \\
Central & $\mathrm{n}$ & 13 & 37 & 19 & 69 \\
& $\%$ & 18.8 & 53.6 & 27.5 & 100 \\
East & $\mathrm{n}$ & 7 & 22 & 30 & 59 \\
& $\%$ & 11.9 & 37.3 & 50.8 & 100 \\
\hline
\end{tabular}

Note : $\mathrm{n}$ is the number of buffalo. 


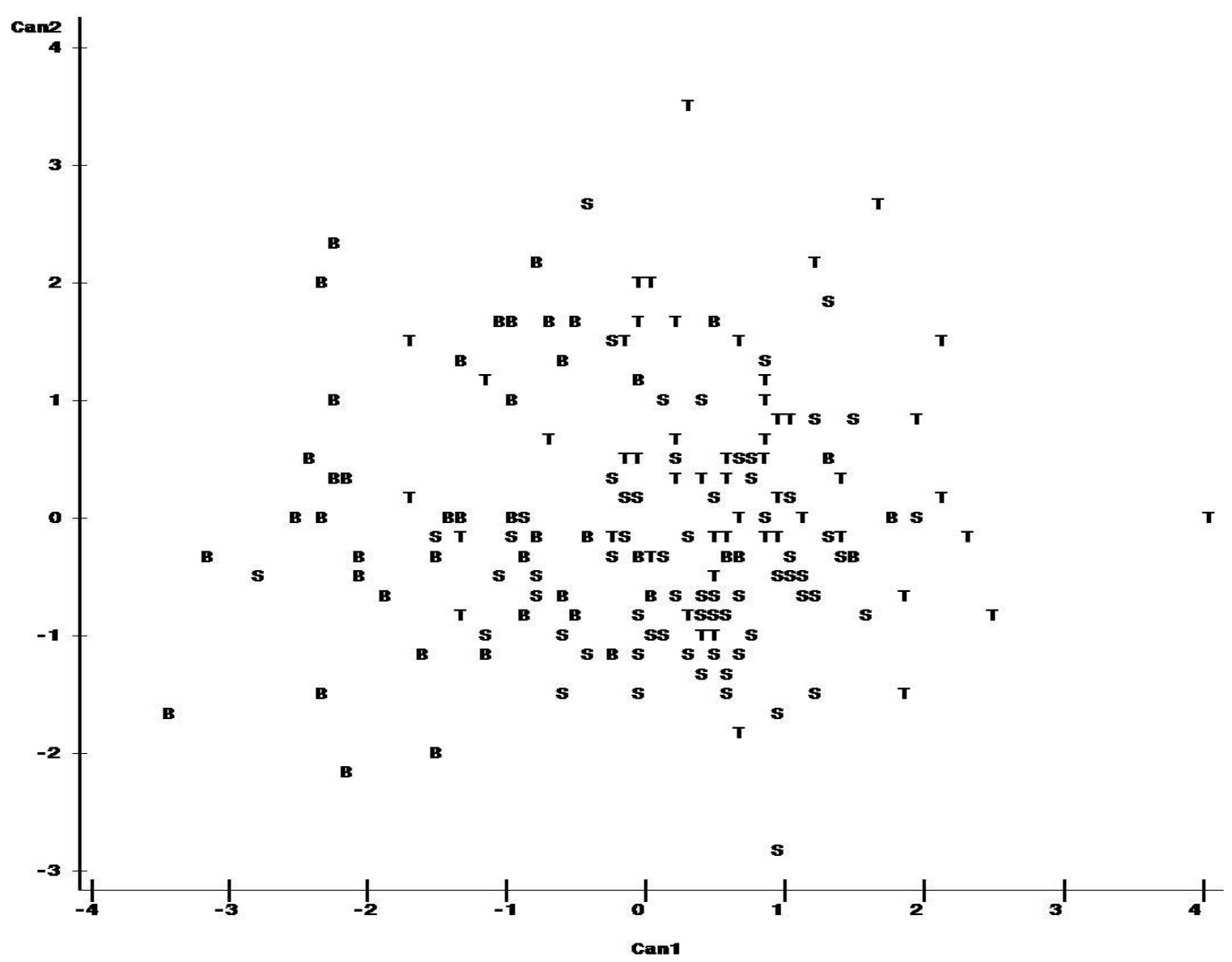

Figure 1. The distribution of Buffalo from subpopulation of west (B), Central (S) and East (T) Areas in Moa Island

higher than central (53.6\%) and east (50.8\%) subpopulations.

Body morphometric character of west subpopulation is influenced by the central subpopulation at $19.6 \%$ dan east subpopulation body morphometric character at $13.0 \%$. Central subpopulation body morphometric character is influenced by west subpopulation at $18.8 \%$ and east subpopulation body morphometric character at $27.5 \%$. Meanwhile, the east subpopulation body morphometric character is influenced by west subpopulation at $11.9 \%$ and central subpopulation body morphometric character at $37.3 \%$.
Genetic distance matrix values between each subpopulation are given in Table 5, and are used to construct phenogram tree (Figure 2). Phenogram tree describes the whole genetic distance of inter-subpopulation of buffalo in Moa island.

In Table 5, it can be seen that the distance between west and central, or west and east subpopulations tend to be far, meanwhile the distance between central and east tend to be near. From the phenogram in Figure 2, it shows that the groupings of buffalo in Moa island occurred, where the west subpopulation is separated from central and east subpopulations, and the central

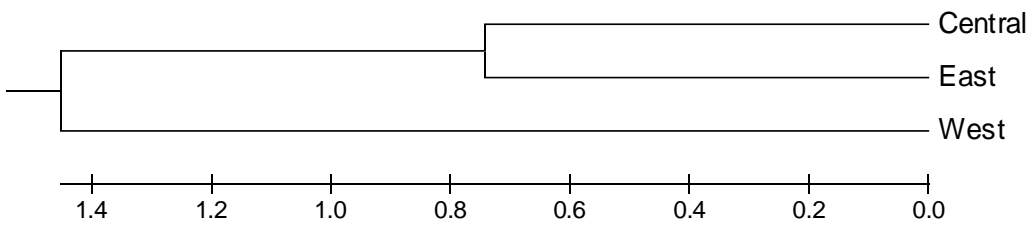

Figure 2. Phenogram between Buffalo Subpopulation in Moa Island 
Table 4. Persentage of Similarity and Mixture Values in and between Buffalo Subpopulation in Moa Island

\begin{tabular}{lccccc}
\hline \multirow{2}{*}{ Subpopulation } & \multicolumn{3}{c}{ Subpopulation } & \multirow{2}{*}{ Total } \\
\cline { 3 - 5 } \multicolumn{2}{l}{ West } & West & Central & East & \\
& $\mathrm{n}$ & 31 & 9 & 6 & 46 \\
\multirow{2}{*}{ Central } & $\%$ & 67.4 & 19.6 & 13 & 100 \\
& $\mathrm{n}$ & 13 & 37 & 19 & 69 \\
\multirow{2}{*}{ East } & $\%$ & 18.8 & 53.6 & 27.5 & 100 \\
& $\mathrm{n}$ & 7 & 22 & 30 & 59 \\
& $\%$ & 11.9 & 37.3 & 50.8 & 100 \\
\hline
\end{tabular}

Note : $\mathrm{n}$ is the number of buffalo.

Table 5. Distance among Buffalo Subpopulation in Moa Island

\begin{tabular}{lccc}
\hline \multirow{2}{*}{ Subpopulation } & \multicolumn{3}{c}{ Subpopulation } \\
\cline { 2 - 4 } West & West & Central & East \\
Central & 0 & & \\
East & 2.75 & 0 & \\
\hline
\end{tabular}

and east subpopulations are in the same group.

Based on the above results, it is found that the West subpoplation tend to be isolated from central and East subpopulations, meanwhile central and East subpopulations tend to mix. Therefore, the central and East subpopulations tend to have similar of body morphometric size compared to West subpopulation. The similarity of body morphometric size found between cattle subpopulations is a reflection of the amount of mixture of groups between subpopulations, either because of the change due to farmer's conduct or occur naturally.

\section{CONCLUSIONS}

Conclusions drawn from the results of the research are: Moa buffalo has specific character, of these characteristics the production performance is related, therefore Moa buffalo has prospect to be developed as meat production to supply the national need. The production-related morphometric character of the buffalo population in Moa island vary, therefore the characters can be taken as selection character to improve the genetic quality of buffalo in Moa island. One character of Moa is variation in body color, with black
$(43.67 \%)$, grey $(28.74 \%)$, white $(15.52 \%)$ and mixture of the three colors (12.07\%). Based on the grouping, the buffalos in central and East regions have genetic distance closeness compared to the ones in West region which are isolated.

\section{ACKNOWLEDGMENT}

This research was part of the Moa buffalo research funded by Higher Education Directorate General, National Education Department according to the Agreement of National Strategy Research Fund No: 02/H13/SPPP-HP/2009 dated 18 April 2009 which was managed by Office of Research Pattimura University Ambon. The authors thanked the Higher Education Directorate General, National Education Department and Office of Research Pattimura University, Ambon.

\section{REFERENCES}

Dinas Pertanian Provinsi Maluku, 2008. Menuju Swasembada Daging 2010. Dinas Pertanian Provinsi Maluku, Ambon.

Diwiyanto, K. and Subandriyo. 1995. Peningkatan mutu genetik kerbau lokal di Indonesia. Jurnal Penelitian dan Pengembangan Pertanian XIV(4): 92-101.

Djanah, D. 1984. Menentukan Umur Ternak. CV Yasaguna, Jakarta.

FAO [Food and Agriculture Organization], 2002. Conserving and Developing Farm Animal Diversity. Secretariat of the Report on the State of the World's Animal Genetics Resources, Rome.

Hardjosubroto, W. 1994. Aplikasi Pemuliaan 
Ternak di Lapangan. PT Grasindo, Jakarta.

Herera, M., E. Rodero, Gutierrez, F. Peria and J.M. Rodero. 1996. Application of multifactorial discriminant analysis in the morphostructural differentiation of Andalusian caprine breeds. Small Rum. Res. 22: 39-47.

Kumar, S., K. Tamura and M. Nei. 1993. MEGA. Molecular Evolutionary Genetics Analysis. Version 1.01. Pennsylvania: Institute of Molecular Evolutioner Genetics, The Pennsylvania University, USA.

Lendhanie, U.U. 2005. Swamp buffalo reproduction characteristic in the community farm condition. Jurnal Bioscientiae vol. 2 (1): 43-48.

Manly, B.F.J. 1989. Multivariate Statistical Method. A Primer. Chapman and Hall Ltd.,
London.

Noovy-Palm, H. 1979. The Sa'dan Toraja: A Study of their social life and religion. Vol. 1 Organization, symbols and beliefs. [The Hague: Nijhoff, Verhandelingen 87]

Puslitnak [Pusat Penelitian Peternakan], 2006. Lokakarya Nasional Pembibitan dan Pengembangan Ternak Kerbau dan Upaya Mendukung Kecukupan Daging 2010, Sumbawa, August 4-5, 2006. Pusat Penelitian Peternakan Badan Litbang Pertanian, Bogor.

Walpole, R.E. 1995. Introduction to Statistics. Edisi ke-3. Gramedia Pustaka Utama, Jakarta.

Yusdja, Y., N. Ilham, and W.K. Sejati. 2003. Profile and Problems in Cattle Farm. Forum Penelitian Agro Ekonomi 21(1): 44-56. 